\title{
MOLECULAR GENETIC VARIATION FOR STRIPE RUST RESISTANCE IN SPRING WHEAT
}

\author{
Muhammad Iqbal $^{1, *}$, Mahwish Ejaz ${ }^{1}$, Iftikhar Ahmed ${ }^{2}$, Armghan Shahzad ${ }^{1}$ and Ghulam M. Ali ${ }^{1}$ \\ ${ }^{1}$ National Institute for Genomics \& Advanced Biotechnology, National Agricultural Research Centre, Islamabad, \\ Pakistan; ${ }^{2}$ National Agricultural Research Center, Islamabad-45500, Pakistan. \\ *Corresponding author's e-mail: iqbal2m@yahoo.com
}

\begin{abstract}
Stripe rust, caused by Puccinia striiformis f. sp. tritici, is a major biotic constraint to global wheat production. Stripe rust can be effectively controlled by developing resistant wheat varieties. This, however, requires identification of resistant sources to be used as parents in breeding programs. Molecular markers provide a quick way of detecting rust resistance genes in adapted wheat material. The present study was conducted to investigate genetic variation for markers linked with stripe rust resistance genes in 67 Pakistani adapted spring wheat varieties using 12 pairs of microsatellite and sequence tagged site markers. Seventy nine percent wheat varieties showed marker allele of Xgwm11 associated with stripe rust resistance gene $\mathrm{Yr} 26$, whereas $75 \%$ varieties had the $\operatorname{Yr} 26$ linked allele of sequence tagged site (STS) marker CYS5. Stripe rust resistance gene $\operatorname{Yr} 5$ was found in 45\%, whereas $\operatorname{Yr} 9$ and $\mathrm{YrlO}$ were present in $28 \%$ varieties tested based on the previously reported linked markers. Stripe rust resistance gene $\operatorname{Yrll}$ was found in 10\%, whereas $\mathrm{Yrl} 18$ in 15\% of varieties only. Three markers Xwe173, Xbarcl81 and Xgwm 140 did not produce the expected amplicons associated with the stripe rust resistance genes. Cluster analysis revealed considerable genetic variation for marker alleles linked with stripe rust resistance genes. Results of this study may be useful for wheat breeders in pyramiding stripe rust resistance genes in future wheat varieties of Pakistan through Marker Assisted Selection.
\end{abstract}

Keywords: DNA Markers, Genetic variation, Marker Assisted Selection, Stripe rust, Triticum aestivum L.

\section{INTRODUCTION}

Wheat stripe rust is caused by Puccinia striiformis f.sp. tritici. It adversely affects the yield and quality of wheat grain. Seeds produced from stripe rust damaged crop have low vigour and poor emergence following germination. Stripe rust pathogen can cause $100 \%$ yield losses in susceptible cultivars if stripe rust occurs at an early stage and the infection continues to develop during wheat's growth. Stripe rust has caused yield losses ranging from 10-70\% in most areas of wheat production (Chen, 2005). The wide range of yield losses depend on the susceptibility of wheat cultivar grown, timing of the initial infection, rate with which stripe rust develops and duration of stripe rust infection (Chen, 2005).

Wheat rusts can either be controlled by spraying chemical fungicides or by developing resistant varieties. Fungicides are expensive, environment non-friendly and need to be applied at a specific growth stage. On the other hand, development of resistant varieties is relatively inexpensive and environment friendly method of controlling rusts. This, however, requires identification of resistant sources to be used as parents in breeding programs. Identification of yellow rust resistance genes and breeding of stripe rust resistant wheat varieties is an efficient approach to minimize wheat yield losses due to stripe rust (Ma et al., 1999). Therefore, wheat breeders and pathologists emphasizes on the development of high yielding and stripe rust resistant wheat varieties in order to combat threats created by new stripe rust races through incorporation of durable rust resistance with the help of marker assisted breeding.

Presently, 48 stripe rust resistance genes (designated as $\mathrm{Yrl}$ Yr48) and several undesignated genes have been identified (McIntosh et al., 2010; McIntosh et al., R. A. 2008). Most of the identified $\mathrm{Yr}$ genes confer resistance to specific stripe rust races at seedling stage. Race-specific $Y r$ genes confer shortlived and non-durable resistance in the field due to the evolution of new virulent races of stripe rust (Kilpatrick, 1975). Deployment of multiple stripe rust resistance genes can broaden the genetic base of future wheat cultivars against stripe rust fungus.

Marker assisted selection is a useful tool in combining multiple $Y r$ genes in a single genotype and in the development of multi-line cultivars having durable rust resistance. Microsatellites or simple sequence repeats (SSRs) are DNA sequence repeats of 1-6 base pairs. They are abundant in eukaryotic genomes and have been commonly used to facilitate identification and incorporation of durable resistance genes of various diseases in wheat (Gupta et al., 1999). Bulos et al. (2006) screened 88 Argentinian wheat cultivars with marker Ventriup-LN2 for the presence of Lr37/Yr17/Sr38 gene complex. Wang et al. (2009) screened 226 wheat cultivars and advance lines from Hungary and 
other countries with the STS marker csLV34 and concluded that this marker can reliably be used for marker assisted selection. McCallum et al. (2012) studied genetic variation for $L r 34 / Y r l 8$ gene in Canadian wheat cultivars using csLV34, cam11, caISBP1 and wms1220 markers. There are number of published reports on the use of DNA markers to detect stripe rust resistance in Pakistani adapted spring wheat. This study was conducted to extend such efforts by investigating genetic variation at the major loci controlling stripe rust resistance in Pakistani adapted spring wheat varieties.

\section{MATERIALS AND METHODS}

The seeds of sixty Pakistani spring wheat varieties released during 1970-2008 (Table 1) were obtained from the Wheat Program of National Agricultural Research Center (NARC), Islamabad, Pakistan. The seeds of the positive and negative controls were acquired from Crop Diseases Research Program (CDRP), NARC, Islamabad.

Genomic DNA was extracted from mature dry seeds of 67 wheat varieties and controls using the following procedure. Four to five seeds of each variety were ground using mortar and pestle and put in a $1.5 \mathrm{uL}$ eppendorf tube. Then, $750 \mathrm{uL}$ of $2 \%$ CTAB solution [(100 mM Tris- $\mathrm{HCl}(\mathrm{pH} 8.0), 20 \mathrm{mM}$ EDTA (pH 8.0), 1.4M NaCl, 2\% CTAB (w/v), 1\% PVP "Polyvinylpyrrolidone Mr.40, 000)] was added to the tube and incubated for $30 \mathrm{~min}$ at $65^{\circ} \mathrm{C}$. Following incubation, 750 uL of Chloroform: Isoamyl Alcohol in the ratio of 24:1 was added to the tube and centrifuged for $10 \mathrm{~min}$ at $12,000 \mathrm{rpm}$. Following centrifugation, supernatant was pipetted into a new $1.5 \mathrm{~mL}$ eppendorf tube and 0.8 volume chilled Isopropanol was added to it. The tube was incubated at $4{ }^{\circ} \mathrm{C}$ for 10 minutes and then centrifuged for $10 \mathrm{~min}$ at $12,000 \mathrm{rpm}$. The supernatant was decanted from tube and DNA pellet was washed 2-3 times with 70\% Ethanol. The DNA pellet was air dried for 15-20 min and dissolved in 50 $\mu \mathrm{L}$ of TE buffer. RNA was removed by treating with $1 \mu \mathrm{L}$ of RNase A $(10 \mathrm{mg} / \mathrm{mL})$ and incubating at $37^{\circ} \mathrm{C}$ for 1 hour. Quantity of DNA in samples was determined by electrophoresis using $1 \%$ agarose gel.

Polymerase chain reaction was performed in $20 \mathrm{uL}$ volume, containing $1 \mathrm{X}$ PCR buffer (containing $\left.\left(\mathrm{NH}_{4}\right)_{2} \mathrm{SO}_{4}\right), 3 \mathrm{mM}$ $\mathrm{MgCl}_{2}, 0.2 \mathrm{mM}$ dNTPs mix, reverse and forward primers (10 pmol each), $1 \mathrm{U}$ of Taq DNA polymerase (Fermentas, Life sciences) and 25-30 ng template DNA. Twelve SSRs and STS markers were used for detecting the presence/absence of several stripe rust resistance genes (Table 2). Amplification was performed in an automated thermal cycler (Applied Biosystems, Veriti 96 well) at $94^{\circ} \mathrm{C}$ for 4 min, followed by 35 cycles each consisting of one denaturation step for 40 s at $94^{\circ} \mathrm{C}$, an annealing step at $72{ }^{\circ} \mathrm{C}$ for 40 s and a step of extension at $72^{\circ} \mathrm{C}$ for $1 \mathrm{~min}$. Following last step, a final extension was performed for $10 \mathrm{~min}$ at $72^{\circ} \mathrm{C}$. Amplified fragments were separated on 1.5-3\% agarose gel (pre-stained with ethidium bromide) and were visualized in Gel Documentation System (UVIpro Platinum, Uvitec, Cambridge, UK). Bands previously proved to be associated with various stripe rust resistance genes were scored based on size. Cluster analysis was performed to group the studied varieties based on similarity of marker alleles using Statistical Analysis Software (SAS) version 9.4 (SAS Institute, Cary, NC, USA).

\section{RESULTS}

We used one microsatellite marker Xgwm120 and two Amplified Fragment Length Polymorphism (AFLP) derived STS marker S19M93-140 and S23M41-310 linked with stripe rust resistance gene $\operatorname{Yr} 5$ to screen 67 Pakistani wheat varieties for the presence of this gene. Microsatellite marker Xgwm120 located $12 \mathrm{cM}$ distal to $\operatorname{Yr} 5$ produced $130-150$ bp marker alleles associated with the presence of $\operatorname{Yr} 5$ in 45 wheat varieties, whereas, 22 varieties showed no amplification, suggesting the absence of Yr5 gene. Marker S19M93-140 produced the expected 100bp fragment in 30 varieties and positive control 'Avocet $\mathrm{Yr}$ 5', indicating the presence of $\mathrm{Yr} 5$ gene while no amplification was observed in negative control and remaining 37 varieties, suggesting the absence of $\operatorname{Yr} 5$ (Fig. 1; Table 1). Marker S23M41-310 amplified a 275 bp band associated with the presence of $\operatorname{Yr} 5$ in positive control and 30 varieties, whereas 37 varieties and negative control 'Avocet S' showed absence of 275 bp band, suggesting absence of $\operatorname{Yr} 5$ in these varieties (Fig. 1; Table 1).

The STS marker iag95 was used to detect the presence of $\mathrm{Yr} 9$ in 67 Pakistani wheat varieties. Nineteen varieties and positive control 'Avocet $\mathrm{Yr}{ }^{9}$ ' showed $1100 \mathrm{bp}$ fragment associated with the presence of stripe rust resistance gene $\mathrm{Yr} 9$. The remaining 48 wheat varieties and negative control did not amplify any fragment, indicating the likely absence of $\operatorname{Yr} 9$ (Fig.2; Table 1).

Microsatellite marker Xpsp3000 was used to determine the presence or absence of $\operatorname{Yr} 10$ gene in Pakistani wheat varieties. Marker Xpsp3000 amplified a 260 bp fragment in 19 Pakistani wheat varieties and positive control 'Avocet $\mathrm{Yr} 10$ ', showing the likely presence of $\mathrm{YrlO}$ gene. The negative control 'Avocet S' and 27 varieties produced $240 \mathrm{bp}$ fragment associated with the absence of yellow rust resistance gene Yr10 (Fig.2; Table 1). Two varieties, Yecora-70 and Shahkar95, showed heterozygous banding pattern. Nine varieties showed a $220 \mathrm{bp}$ fragment, not reported previously, indicating that these varieties may have novel allele at $\mathrm{Yr} 10$ locus. Eight varieties did not produce any fragment, therefore, we could not determine the $\mathrm{YrlO}$ status of these varieties.

The presence of $\operatorname{Yrl} 17$ gene in Pakistani wheat was investigated with the primers VENTRIUP and LN2 (Helguera et al., 2003). Seven varieties viz. Zardana-89, Shahkar-95, Suleman-96, MH-97, Fakhar-e-Sarhad, GA-2002, Moomal- 
2002 and the positive control 'Avocet $\operatorname{Yr} 17$ ' showed a 259bp fragment (Table 1), indicating the presence of $Y r 17$ gene.

Table 1. Allelic variation at marker loci linked with stripe rust resistance genes in Pakistani spring wheat varieties

\begin{tabular}{|c|c|c|c|c|c|c|c|c|c|c|}
\hline \multirow[t]{2}{*}{ *No. } & \multirow[t]{2}{*}{ Variety } & \multicolumn{2}{|c|}{ Yr5 } & \multirow{2}{*}{$\begin{array}{c}Y r^{9} 9 \\
\text { iag95 }\end{array}$} & \multirow{2}{*}{$\begin{array}{c}\text { Yr10 } \\
X p s p 3000 \\
\end{array}$} & \multirow{2}{*}{$\begin{array}{c}\text { Yr17 } \\
\text { Ventriup-LN2 } \\
\end{array}$} & \multicolumn{2}{|c|}{ Yr18 } & \multicolumn{2}{|c|}{ Yr26 } \\
\hline & & $519 M 93-140$ & $523 M 41-310$ & & & & csLV34 & Cssfr-5 & Xgwm11 & CYS-5 \\
\hline 01 & Barani-70 & - & - & & $\mathrm{M}$ & & & & + & + \\
\hline 02 & Lyallpur-73 & - & - & - & - & - & + & + & + & - \\
\hline 03 & Yecora-70 & + & + & - & $+/-$ & - & $+/-$ & + & + & - \\
\hline 04 & Punjab-76 & - & - & - & - & - & $+/-$ & + & + & + \\
\hline 05 & Lu-26 & + & + & - & + & - & $+/-$ & - & + & + \\
\hline 06 & Pavon-76 & + & + & + & - & - & - & - & $?$ & - \\
\hline 07 & Zarghoon-79 & - & - & - & $\mathrm{N}$ & - & - & - & + & + \\
\hline 08 & Pak-81 & - & - & + & $\mathrm{N}$ & - & - & - & - & + \\
\hline 09 & Kohinoor-83 & + & + & + & $\mathrm{N}$ & - & - & & - & + \\
\hline 10 & Tandojam-83 & - & - & - & - & - & + & M & + & - \\
\hline 11 & Pirsabak-85 & - & - & + & - & - & & - & + & + \\
\hline 12 & Sarsabz & - & - & - & - & - & M & - & + & + \\
\hline 13 & Chakwal-86 & + & + & - & + & - & & - & + & + \\
\hline 14 & Khyber-87 & + & + & + & - & - & $+/-$ & + & - & - \\
\hline 15 & Shalimar- 88 & - & - & - & + & - & - & - & + & + \\
\hline 16 & Zardana-89 & - & - & - & + & + & - & - & + & + \\
\hline 17 & Soghat-90 & 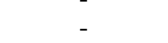 & 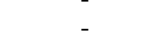 & - & $\mathrm{N}$ & - & $=$ & $=$ & + & $\begin{array}{l}+ \\
+\end{array}$ \\
\hline 18 & Pasban-90 & + & + & + & - & - & - & - & - & + \\
\hline 19 & Inqilab-91 & + & + & - & - & - & - & - & + & + \\
\hline 20 & Sariab-92 & + & + & - & + & - & - & - & + & + \\
\hline 21 & Bakhtawar-92 & + & + & + & - & - & + & + & - & + \\
\hline 22 & Pothowar-93 & - & - & - & + & - & + & $+/-$ & + & + \\
\hline 23 & Kiran-95 & + & + & - & - & - & M & - & + & + \\
\hline 24 & Shahkar-95 & + & + & + & +- & + & $+/-$ & $+/-$ & + & + \\
\hline 25 & Suleman-96 & - & - & - & + & + & - & + & + & + \\
\hline 26 & Tatara & + & + & + & M & 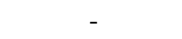 & - & - & - & + \\
\hline 27 & Nowshera-96 & + & + & - & + & - & - & - & + & + \\
\hline 28 & MH-97 & - & - & - & + & + & M & - & + & + \\
\hline 29 & Chakwal-97 & + & $?$ & - & M & & $+/-$ & - & + & + \\
\hline 30 & Fakhr-e-Sarhad & - & - & - & - & + & $+/-$ & - & + & + \\
\hline 31 & Koshistan-97 & + & + & + & + & - & M & $+/-$ & + & + \\
\hline 32 & Zarlashta-99 & - & - & + & - & - & - & - & + & + \\
\hline 33 & Auqab-2000 & - & - & + & + & - & - & - & + & + \\
\hline 34 & Saleem-2000 & + & + & - & $\mathrm{N}$ & - & + & + & + & + \\
\hline 35 & Marvi-2000 & + & + & + & - & - & - & - & + & + \\
\hline 36 & Wafaq-2001 & + & + & - & + & - & - & - & - & + \\
\hline 37 & GA-2002 & - & - & + & $\mathrm{N}$ & + & - & $+/-$ & + & + \\
\hline 38 & Moomal-2002 & - & - & + & - & + & - & - & - & + \\
\hline 39 & SH-2003 & + & + & - & M & - & - & - & + & + \\
\hline 40 & Raskoh-2005 & - & - & - & - & - & - & - & + & - \\
\hline 41 & Pirsabak-05 & + & + & - & M & - & $+/-$ & - & + & - \\
\hline 42 & Sehar-2006 & - & - & + & $\mathrm{N}$ & - & - & - & + & + \\
\hline 43 & Shafaq-2006 & + & + & - & + & - & - & - & - & - \\
\hline 44 & Sassui & - & - & - & - & - & - & - & + & + \\
\hline 45 & NARC-09 & + & + & + & $\mathrm{N}$ & - & - & - & + & + \\
\hline 46 & NR-281 & - & - & - & M & - & $+/-$ & + & - & - \\
\hline 47 & NR-287 & - & - & - & - & - & - & - & + & + \\
\hline 48 & Local White & - & - & - & + & $=$ & - & - & + & + \\
\hline $\begin{array}{l}48 \\
49\end{array}$ & S-24 & - & 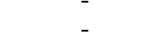 & - & $\begin{array}{l}+ \\
+\end{array}$ & - & $=$ & $=$ & $\begin{array}{l}+ \\
+\end{array}$ & $\begin{array}{l}+ \\
+\end{array}$ \\
\hline 50 & Mexi Pak & - & - & - & - & - & - & - & + & + \\
\hline 51 & SARC-1 & + & + & - & - & - & - & - & + & - \\
\hline 52 & Sonalika & + & + & - & - & - & - & - & + & + \\
\hline 53 & NR-360 & - & - & - & $\mathrm{N}$ & - & - & - & + & - \\
\hline 54 & Blue silver & + & + & - & M & - & - & - & + & - \\
\hline 55 & Faisalabad-08 & - & - & - & - & - & - & - & + & + \\
\hline 56 & Lasani-08 & - & - & - & - & - & - & - & + & M \\
\hline 57 & Panjnad & - & - & - & - & - & - & + & + & M \\
\hline 58 & Mairaj-08 & + & + & + & - & - & - & - & + & M \\
\hline 59 & Chakwal-50 & - & - & - & M & - & - & - & + & M \\
\hline 60 & Fareed-06 & + & + & - & - & - & - & + & M & M \\
\hline 61 & Millat-2011 & + & + & - & + & - & - & - & + & + \\
\hline 62 & Dharabi-2011 & - & + & - & + & - & - & - & + & + \\
\hline 63 & Pakistan-2011 & 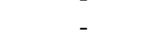 & - & - & + & - & - & - & $\begin{array}{l}+ \\
+\end{array}$ & $\begin{array}{l}+ \\
+\end{array}$ \\
\hline 64 & Galaxy-2013 & - & - & - & - & - & + & - & + & + \\
\hline 65 & Benazir-2013 & + & + & - & M & - & - & - & + & + \\
\hline 66 & Pirsabak-2013 & - & - & + & M & - & - & - & - & + \\
\hline 67 & NIFA Lalima & - & - & - & + & 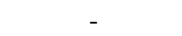 & - & - & - & + \\
\hline & Frequency & 30 & 30 & 19 & 19 & 7 & 6 & 10 & 53 & 50 \\
\hline
\end{tabular}


* indicates the same number as in the figures, ${ }^{+}$indicates marker allele associated with presence, whereas "-، indicates marker allele associated with absence of gene. $\mathrm{M}=$ missing; $\mathrm{N}=$ marker allele previously not reported

Table 2 DNA markers linked with different stripe rust resistance genes in wheat

\begin{tabular}{|c|c|c|c|c|c|c|}
\hline No & Marker & $\mathbf{T a}^{\mathbf{a}}$ & Linkage & Product $(b p)^{b}$ & Distance & Reference \\
\hline 1 & S19M93-100 & 62 & Yr5 & $\mathrm{P}=100$ & Diagnostic & Smith et al. (2007) \\
\hline 2 & S23M41-275 & 58 & $\operatorname{Yr} 5$ & $\mathrm{P}=275$ & $0.7 \mathrm{cM}$ & Smith et al. (2007) \\
\hline 3 & Xgwm120 & 60 & $\operatorname{Yr} 5$ & $\mathrm{P}=120$ & $38.4 \mathrm{cM}$ & Smith et al. (2007) \\
\hline 4 & iag95 & 55 & $\operatorname{Yr} 9$ & $P=1100$ & Diagnostic & Mago et al. (2002) \\
\hline 5 & Xpsp3000 & 55 & $\operatorname{Yr} 10$ & $\begin{array}{l}P=260 \text { or } 285 \\
A=240\end{array}$ & $2.7 / 3.5 \%$ & Bariana et al. (2002) \\
\hline 6 & Ventriup/LN2 & 65 & Yr17 & $\mathrm{P}=259$ & Diagnostic & Helguera et al. (2003) \\
\hline 7 & $\operatorname{csLV} 34$ & 58 & $\operatorname{Yr} 18$ & $\begin{array}{l}\mathrm{P}=150 \\
\mathrm{~A}=229\end{array}$ & Diagnostic & Lagudah et al. (2006) \\
\hline 8 & cssfr-5 & 58 & $\operatorname{Yr} 18$ & $\begin{array}{l}\mathrm{P}=751 \\
\mathrm{~A}=523\end{array}$ & Diagnostic & Lagudah et al. (2009) \\
\hline 9 & CYS -5 & 55 & Yr26 & $\mathrm{P}=348$ & $0.5 \mathrm{cM}$ & Wen et al. (2008) \\
\hline 10 & Xgwml1 & 55 & Yr15\&Yr26 & $\mathrm{P}=215$ & $1.9 \mathrm{cM}$ & Ma et al. (2001) \\
\hline
\end{tabular}

a Annealing temperature in degrees Celsius

$\mathrm{b}$ indicates presence whereas A indicates absence of gene.

${ }^{c}$ Recombination frequency
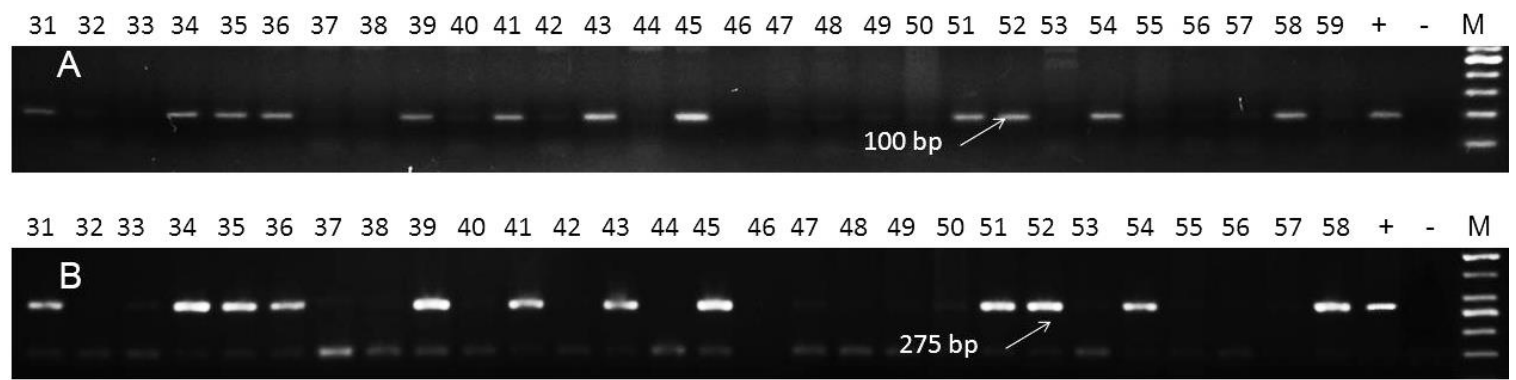

Figure 1. PCR amplification of (A) S19M93-140 locus in Pakistani spring wheat, (B) Marker S23M41-310 for Yr5. $M=50 \mathrm{bp}$; + means positive (Avocet $\mathrm{Yr}$ 5) whereas - means negative control 'Avocet $S$ '.

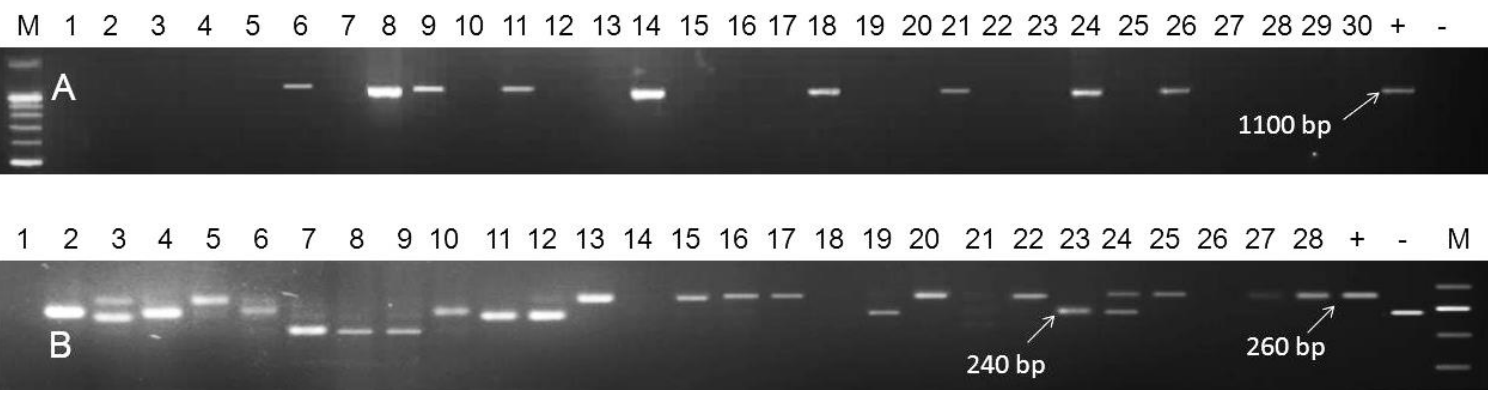

Figure 2. PCR amplification of (A) Yr9-linked marker iag95 in Pakistani wheat for $M=100 \mathrm{bp},+$ means positive control 'Avocet Yr9', while - means negative control 'Avocet', (B) Markers Psp3000 for Yr10 gene M=50bp; + means positive control 'Avocet $Y r 10$ ' while - means negative control 'Avocet $S$ '.

The remaining 60 varieties and 'Avocet S' did not produce the $259 \mathrm{bp}$ fragment, suggesting the absence of $\operatorname{Yr} 17$.

The presence of stripe rust resistance gene $\mathrm{Yr} 18$ was assayed using a STS marker csLV34 and gene specific marker cssfr5. The STS marker $c s L V 34$ having 79 bp insertion within the intronic sequence of sulphate transporter-like gene (Lagudah et al., 2006) produced two allelic variants i.e. csLV34a and $c s L V 34 b$. Out of 67 varieties, 48 varieties showed $c s L V 34 a$ Yrl8-linked allele of $229 \mathrm{bp}$, indicating absence of $\mathrm{Yr} 18$ gene, whereas, six varieties amplified 150bp fragment, suggesting the presence of $Y r 18$-associated allele $c s L V 34 b$ (Table 1). Moreover, nine varieties produced both alleles showing heterozygous banding pattern and four varieties did not show any of the two amplicons. The gene specific marker cssfr 5 

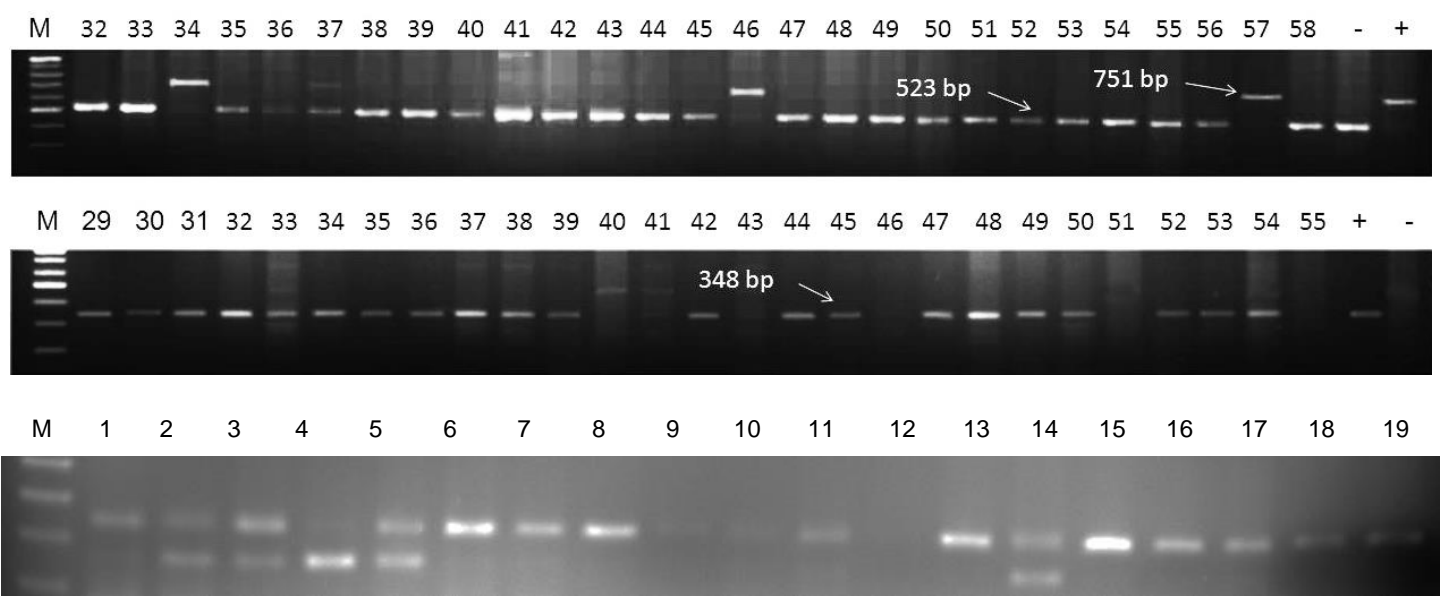

Figure 3. PCR amplification pattern of (A) marker cssfr-5 linked with Yr18. (B) Banding pattern of marker CYS-5 associated with Yr26, (C) marker csLV34 linked with Yr18 gene in Pakistani wheat (M=100 bp). + Means positive 'Avocet $\mathrm{Yr} 18$ ' and 'Avocet $\mathrm{Yr26}$ ' respectively, while - means negative control 'Avocet $\mathrm{S}$.

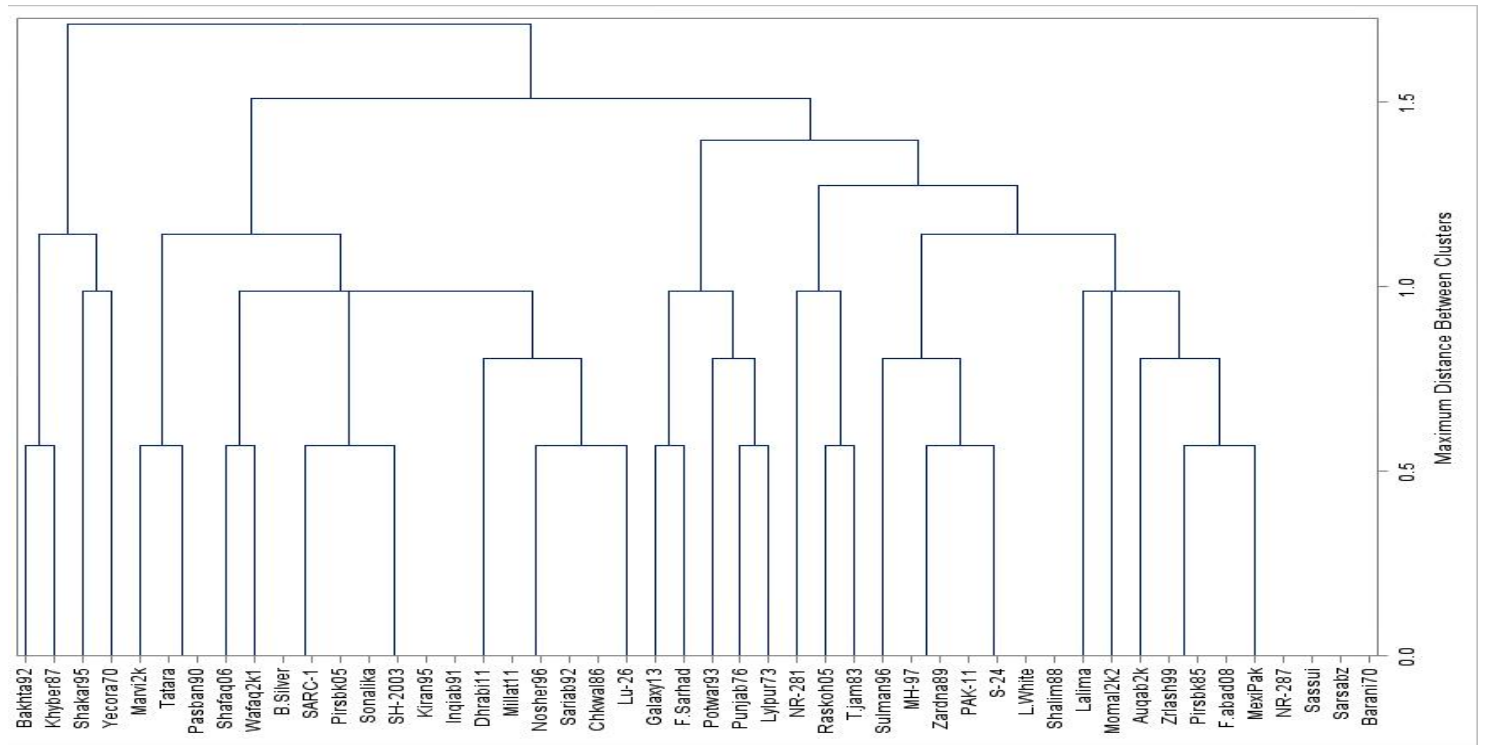

Figure 4. Dendogram showing grouping of Pakistani wheat varieties based on 9 markers linked with stripe rust resistance genes.

showed two alleles of 523 and $751 \mathrm{bp}$, respectively in this study. Fifty two varieties showed the presence of $523 \mathrm{bp}$ band associated with absence of $\operatorname{Yr} 18$, whereas $751 \mathrm{bp}$ fragment was amplified only in 10 varieties, suggesting the presence of Yrl8 gene (Fig 3; Table 1). Four varieties exhibited the heterozygous banding pattern, whereas one variety did not show amplification.

We used four markers Xgwm11, Xwe173, Xbarc181 and CYS-5 to detect the presence/absence of $Y r 26$. Microsatellite markers $X g w m 11$ and $X b a r c 181$ are 1.9 and $6.7 \mathrm{cM}$ distal to Yr26, whereas EST based STS marker Xwe173 has been mapped $1.4 \mathrm{cM}$ from Yr26 (Wang et al., 2008). Marker Xgwm11 amplified a 215bp fragment in 53 Pakistani wheat varieties and positive control, indicating the likely presence of $\operatorname{Yr26}$, whereas 13 varieties and negative control did not produce any fragment (Table 1). We could not obtain previously reported results with marker Xwe173. STS marker CYS -5 has been developed from resistance gene analogs and is located $0.5 \mathrm{cM}$ away from $\operatorname{Yr} 26$ (Wen et al., 2008). In our study, 50 varieties and positive control produced a $348 \mathrm{bp}$ fragment with marker CYS-5, indicating the presence of Yr26, whereas 12 varieties and negative control did not yield any fragment showing the absence of this gene (Fig. 3; Table 1).

Cluster analysis grouped 44 of the 67 wheat varieties into 3 major clusters (Fig. 4), whereas 23 varieties remained ungrouped. Each of the three major clusters had both old and new wheat varieties, indicating that breeding efforts have not 
favoured a particular allele over the other over the period of time. The lack of grouping of the 23 varieties suggested that these were genetically more variable with respect to the marker alleles studied.

\section{DISCUSSION}

The present study was conducted to detect stripe rust resistance genes in 67 Pakistani adapted spring wheat varieties using 12 pairs of microsatellite and sequence tagged site markers. Nine markers viz: S19M93-140, S23M41-310, Xgwm120, iag95, Ventriup-LN2, Xgwm11, csLV34, CYS5 and cssfr 5 produced expected results whereas three markers viz: Xwe173, Xbarc181 and Xgwm140 failed to produce the desired band size associated with the stripe rust resistance genes.

Stripe rust resistance gene $\operatorname{Yr} 5$ is expressed at seedling stage (Macer, 1963), and is mapped on chromosome 2BL (Law, 1976). Our results of marker $S 23 M 41-310$ were different from Smith et al. (2007) as they reported the presence of $210 \mathrm{bp}$ fragment in $\mathrm{Yr} 5$ non-carriers. The $210 \mathrm{bp}$ was not produced in Pakistani varieties studied. Instead, we observed a faint band of $275 \mathrm{bp}$ fragment in some of the $\operatorname{Yr} 5$ non-carriers. We compared the results of all three markers used to detect the presence/absence of $Y r 5$ gene. Results for markers S19M93140 and S23M41-310 were 99\% similar, demonstrating the likely presence of $Y r 5$ in $45 \%$ of Pakistani wheat varieties studied. On the contrary, results of microsatellite Xgwm120 were different from these two STS markers and produced variable fragment sizes. Moreover, this marker is $12 \mathrm{cM}$ distal to $Y r 5$, which does not make it a diagnostic marker for $Y r 5$. Marker S19M93-140 has been reported to be co-segregating with $\mathrm{Yr} 5$ gene making it more reliable marker compared to S23M41-310 which is 0.7 mapped cM from $\operatorname{Yr} 5$ (Smith et al., 2007). However, both these markers are equally diagnostic and reliable and may be used for the routine screening of wheat germplasm for $Y r 5$.

AFLP converted STS marker iag95 is reported diagnostic for the detection of 1BL.1RS translocation segment that carries Sr31/Yr9/Lr26/Pm8 genes (Mago et al., 2002). This marker has been previously used the detection of stem rust resistance gene Sr31 in Pakistani wheat varieties by Ejaz et al. (2012). Pretorius et al. (2010) reported the usefulness of this marker to detect stem rust resistance gene Sr31 in African wheat germplasm. Despite the fact that marker iag95 is diagnostic for the detection of $\mathrm{Yr} 9$, its dominant nature does not allow to distinguish between heterozygous and homozygous dominant varieties. Hence, its usefulness for selection of $\operatorname{Yr} 9$ in segregating generations is limited.

Stripe rust resistant gene $\mathrm{Yr} 10$ was originated from a Turkish wheat line P.I.178383 (Wang et al., 2002). It was mapped on chromosome 1BS, 2cM apart from $R g 1$ locus that confers brown glume colour (Metzger and Silbaugh, 1970) and 5cM from locus Gli-1B (Payne et al., 1986). Rgl is a phenotypic marker for the selection of $\mathrm{Yr} 10$ but it can only be used at adult plant stage (Metzger and Silbaugh, 1970). Bariana et al. (2002) reported two alternative alleles for yellow rust resistant gene $\mathrm{YrlO}$ i.e. $\mathrm{YrlO}$ and Yrvav. They described the association of marker Xpsp3000 marker with both genes $\mathrm{YrlO}$ and Yrvav. Our study demonstrated that $28 \%$ wheat varieties produced $260 \mathrm{bp}$ fragments, indicating the presence of $\mathrm{Yr} 10$ but none of them amplified 285bp band associated with the Yrvav allele. Instead, nine varieties showed a $220 \mathrm{bp}$ fragment, which hasn't been reported previously. Therefore, this allele may be a novel allele. As $\operatorname{Yr} 10$ is also linked with locus Gli$B$ on chromosome 1BS (Payne et al., 1986), hence, a combine assay of Xpsp3000 and Gli-B would be more reliable to evaluate the germplasm for screening and pyramiding of $\mathrm{Yr} 10$ gene into adapted varieties.

Alien chromosomal segment carrying three rust resistance genes i.e. $\mathrm{Lr} 37$, Sr38, and $\mathrm{Yr} 17$, was translocated into bread wheat from 2NS chromosome of Triticum ventricosum (Maia, 1967). Only 7 of the studied wheat varieties had Yr17-Lr37Sr38 gene complex. Although, virulence to $\mathrm{Yr} 17$ has been detected in various parts of the world (Robert et al., 2000); J. Kolmer unpublished data), but it can still provide resistance against various stripe rust races if pyramided with other $\mathrm{Yr}$ genes.

Locus Yr18/Lr34/Pm38 provides adult plant resistance against stripe rust, leaf rust and powdery mildew (McIntosh, 1992; Singh, 1992; Spielmeyer et al., 2005). Moreover, this segment is also associated with barley yellow dwarf virus resistance gene $B d v l$ (Singh, 1993) and tolerance to black rust (Dyck, 1993). STS marker csLV34 is $0.4 \mathrm{cM}$ distal to Yr18/Lr34 (Lagudah et al., 2006) and is diagnostic for the detection of heterozygotes in the segregating population due to its co-dominant nature. Kolmer et al. (2008) reported the usefulness of this marker for detecting the presence/absence of $L r 34 / Y r 18$ in a diverse range of wheat germplasm. Allele specific marker cssfr 5 has been developed from $3 \mathrm{bp}$ indel sequence polymorphism in $\mathrm{Yr} 18$-linked gene $\mathrm{Lr} 34$, first rust resistance gene to be sequenced (Lagudah et al., 2009). We compared the results of csLV34 and cssfr 5 markers in order to determine the reliability of these markers. The marker comparison showed some discrepancies for the presence/absence of $\operatorname{Lr} 34 / \mathrm{Yr} 18$. However, cssfr5 is more reliable as it is a gene specific marker and thus should be preferred for the MAS of this gene complex. Based on the results of cssfr5, only 10 (15\%) Pakistani wheat varieties had Lr34/Yrl8 gene complex. As this gene complex provides durable adult plant resistance, its frequency should be increased in future wheat varieties of Pakistan so that their genetic base can be broadened against the continually evolving new races of Puccinia striiformis tritici.

Stripe rust resistance genes $\mathrm{Yr} 26, \mathrm{Yr} 24$ and $\mathrm{YrCH} 42$ are considered to be identical genes as they produced similar infection types against 26 rust isolates (Li et al., 2006). $Y r 26$ is located on chromosome 1B (Ma et al., 2001) and is 
effective against majority of the $P$ st races. Combined results of Xgwmll and CYS-5 markers exhibited the presence of $Y r 26$ in 41 varieties, whereas four varieties were found non-carriers of $Y r 26$ based on the results of both markers. The results of 17 varieties were dissimilar in the marker comparison. Thus, we suggest that use of STS marker CYS-5 is more reliable compared to microsatellite $\mathrm{Xgwm} 11$, because the latter is only $1.9 \mathrm{cM}$ distal to $\mathrm{Yr} 26$. Marker assay showed that $75-79 \%$ varieties exhibited the presence of $Y r 26$ gene. Marker Xgwm11 has also been reported linked with Yrl5.

Stripe rust is one of the major biotic production constraints in Pakistan. Stripe rust epidemics have occurred from time to time with $35 \%$ intensity during 1973 , 55\% during 1978, 38\% during 1995 and 20\% during 2003 in Pakistan (Ahmad, I. 2004). Virulent races of Pst have broken down the resistance of major deployed genes such as $\mathrm{Yr} 9$ (in Mexipak and Pak81) and $Y r 27$ (Inqalab-91) with the passage of time (Khan and Mumtaz, 2004). The breakdown of major stripe rust resistance genes has alarmed wheat breeders for broadening the genetic base of future Pakistani wheat varieties by incorporating multiple stripe rust resistance genes. This objective can be achieved by first determining the status of $\mathrm{Yr}$ genes of Pakistani adapted wheat varieties through an efficient method such as DNA markers. Marker assisted selection can provide as an efficient means of pyramiding $\mathrm{Yr}$ genes. In this study, the maximum frequency of stripe rust resistance gene was observed for $\operatorname{Yr} 26$ (75-79\%), followed by Yr5 (45\%), YrlO (28\%), Yr9 (28\%), Yr18 (9-15\%) and Yrl7 (10\%), respectively. Results of this study can be useful for wheat breeders in pyramiding rust resistance genes in future wheat varieties using Marker Assisted Selection.

Acknowledgement: The authors are grateful to Wheat Program, National Agricultural Research Centre for provision of seeds. Financial support from Pakistan Agricultural Research Council under Research for Agricultural Development Program (RADP) is also acknowledged.

\section{REFERENCES}

Ahmad, I. 2004. Wheat Rust Scenario 2003-2004. Second Regional Yellow Rust Conference for Central \& West Asia and North Africa, March 22-26, 2004, Islamabad, Pakistan.

Bariana, H., G. Brown, N. Ahmed, S. Khatkar, R. Conner, C. Wellings, S. Haley, P. Sharp and A. Laroche. 2002. Characterisation of Triticum vavilovii-derived stripe rust resistance using genetic, cytogenetic and molecular analyses and its marker-assisted selection. Theor. Appl. Genet. 104: 315-320.

Bulos, M., M. Echarte and C. Sala. 2006. Occurrence of the rust resistance gene Lr37 from Aegilops ventricosa in Argentine cultivars of wheat. Electron. J. Biotechnol. 9: 5 .
Chen, X. 2005. Epidemiology and control of stripe rust [Puccinia striiformis f. sp. tritici] on wheat. Can. J. Plant Pathol. 27: 314-337.

Dyck, P. 1993. Inheritance of leaf rust and stem rust resistance in'Roblin'wheat. Genome 36: 289-293.

Ejaz, M., M. Iqbal, A. Shahzad, I. Ahmed and G. M. Ali. 2012. Genetic variation for markers linked to stem rust resistance genes in Pakistani wheat varieties. Crop Sci. 52: 2638-2648.

Gupta, P., R. K. Varshney, P. Sharma and B. Ramesh. 1999. Molecular markers and their applications in wheat breeding. Plant Breed. 118: 369-390.

Helguera, M., I. Khan, J. Kolmer, D. Lijavetzky, L. Zhong-Qi and J. Dubcovsky. 2003. PCR assays for the cluster of rust resistance genes and their use to develop isogenic hard red spring wheat lines. Crop Sci. 43: 1839-1847.

Khan, M.A. and H. Mumtaz. 2004. Combining yellow rust resistance with high yield in grain wheat. . Second Regional Yellow Rust Conference for Central and West Asia and North Africa, March 22-26, 2004, Islamabad, Pakistan.

Kilpatrick, R. 1975. New wheat cultivars and longevity of rust resistance, 1971-1975. Beltsville, MD: US Department of Agriculture. Agricultural Research Service 20.

Kolmer, J.A., R.P. Singh, D.F. Garvin, L. Viccars, H.M. William, J. Huerta-Espino, F.C. Ogbonnaya, H. Raman, S. Orford and H.S. Bariana. 2008. Analysis of the Rust Resistance Region in Wheat Germplasm. Crop Sci. 48: 1841-1852.

Lagudah, E., H. McFadden, R. Singh, J. Huerta-Espino, H. Bariana and W. Spielmeyer. 2006. Molecular genetic characterization of the $\mathrm{Lr} 34 / \mathrm{Yr} 18$ slow rusting resistance gene region in wheat. Theor. Appl. Genet. 114: 21-30.

Lagudah, E.S., S.G. Krattinger, S. Herrera-Foessel, R.P. Singh, J. Huerta-Espino, W. Spielmeyer, G. BrownGuedira, L.L. Selter and B. Keller. 2009. Gene-specific markers for the wheat gene Lr34/Yr18/Pm38 which confers resistance to multiple fungal pathogens. Theor. Appl. Genet. 119: 889-898.

Law, C. N. 1976. Genetic control of yellow rust resistance in Triticum aestvium ssp spelta var album. Plant Breeding Institute, Cambridge. pp.108-109.

Li, G., Z. Li, W. Yang, Y. Zhang, Z. He, S. Xu, R. Singh, Y. Qu and X. Xia. 2006. Molecular mapping of stripe rust resistance gene $\mathrm{YrCH} 42$ in Chinese wheat cultivar Chuanmai 42 and its allelism with $Y r 24$ and $Y r 26$. Theor. Appl. Genet. 112: 1434-1440.

Ma, J., R. Zhou, Y. Dong, L. Wang, X. Wang and J. Jia. 2001. Molecular mapping and detection of the yellow rust resistance gene $\mathrm{Yr} 26$ in wheat transferred from Triticum turgidum L. using microsatellite markers. Euphytica 120: 219-226.

Ma, J., R. Zhou, Y. Dong, X. Wang and J. Jia. 1999. Molecular mapping of a novel yellow rust resistance gene 
of wheat using microsatellite markers. Chinese Science Bulletin 44: 1774-1778.

Macer, R.C.F. 1963. The formal and monosomic genetic analysis of stripe rust (Puccinia striiformis) resistance in wheat. Proceedings of the 2nd international wheat genetics symposium, Lund, Sweden.

Mago, R., W. Spielmeyer, G. Lawrence, E. Lagudah, J. Ellis and A. Pryor. 2002. Identification and mapping of molecular markers linked to rust resistance genes located on chromosome $1 \mathrm{RS}$ of rye using wheat-rye translocation lines. Theor. Appl. Genet. 104: 1317-1324.

Maia, N. 1967. Obtention des blés tendres resistants au pietinverse par croisements interspecifiques blés X Aegilops. Comptes Rendus des Séances de l'Académie d'Agriculture de France 53: 149-154.

McCallum, B.D., D.G. Humphreys, D.J. Somers, A. Dakouri and S. Cloutier. 2012. Allelic variation for the rust resistance gene $\operatorname{Lr34/Yr18}$ in Canadian wheat cultivars. Euphytica 183: 261-274.

McIntosh, R. 1992. Close genetic linkage of genes conferring adult-plant resistance to leaf rust and stripe rust in wheat. Plant Pathol. 41: 523-527.

McIntosh, R.A., J. Dubcovsky, J. Rogers, C. Morris, R. Appels and X.C. Xia. 2010. Catalogue of gene symbols for wheat: 2010 supplement. Annual Wheat Newsletter 56: 273-282.

McIntosh, R.A., Y. Yamazaki, J. Dubcovsky, J. Rogers, C. Morris, D.J. Somers, R. Appels and K.M. Devos. 2008. Catalogue of gene symbols for wheat. 11th Int. Wheat Genet. Symp., Sydney. Sydney University Press, Sydney.

Metzger, R. and B. Silbaugh. 1970. Inheritance of resistance to stripe rust and its association with brown glume color in Triticum aestivum L., 'PI 178383'. Crop Sci. 10: 567568.

Payne, P., L. Holt, R. Johnson and J. Snape. 1986. Linkage mapping of four gene loci, Glu-B1, Gli-B1, Rg1 and $\operatorname{Yr} 10$ on chromosome 1B of bread wheat. Genet. Agrar. 40: 231-242.
Pretorius, Z., C. Bender, B. Visser and T. Terefe. 2010. First report of a Puccinia graminis $f$. sp. tritici race virulent to the $\operatorname{Sr} 24$ and $S r 31$ wheat stem rust resistance genes in South Africa. Plant Dis. 94: 784-784.

Robert, O., F. Dedryver, M. Leconte, B. Rolland and C.D. Vallavieille-Pope. 2000. Combination of resistance tests and molecular tests to postulate the yellow rust resistance gene $\operatorname{Yr} 17$ in bread wheat lines. Plant Breed. 119: 467472 .

Singh, R. 1992. Genetic association of leaf rust resistance gene Lr34 with adult plant resistance to stripe rust in bread wheat. Phytopathol. 82: 835-838.

Singh, R.P. 1993. Resistance to leaf rust in 26 Mexican wheat cultivars. Crop Sci. 33: 633-637.

Smith, P., P. Donini, J. Hadfield, N. Hart, R. Koebner and L. Boyd. 2007. STS markers for the wheat yellow rust resistance gene $\operatorname{Yr} 5$ suggest a NBS-LRR-type resistance gene cluster. Genome 50: 259-265.

Spielmeyer, W., R. McIntosh, J. Kolmer and E. Lagudah. 2005. Powdery mildew resistance and Lr34/Yr18 genes for durable resistance to leaf and stripe rust cosegregate at a locus on the short arm of chromosome 7D of wheat. Theor. Appl. Genet. 111: 731-735.

Wang, C., Y. Zhang, D. Han, Z. Kang, G. Li, A. Cao and P. Chen. 2008. SSR and STS markers for wheat stripe rust resistance gene $Y r 26$. Euphytica 159: 359-366.

Wang, L., J. Ma, R. Zhou, X. Wang and J. Jia. 2002. Molecular tagging of the yellow rust resistance gene $\mathrm{Yr} 10$ in common wheat, PI 178383 (Triticum aestivum L.). Euphytica 124: 71-73.

Wang, L., Z. Zhang, H. Liu, S. Xu, M. He, H. Liu, O. Veisz and Z. Xin. 2009. Identification, gene postulation and molecular tagging of a stripe rust resistance gene in synthetic wheat CI142. Cereal Res. Comm. 37: 209-215.

Wen, W., G. Li, Z. He, W. Yang, M. Xu and X. Xia. 2008. Development of an STS marker tightly linked to Yr26 against wheat stripe rust using the resistance gene-analog polymorphism (RGAP) technique. Mol. Breed. 22: 507515. 